\title{
Industrial Relations in the Republic of Ireland
}

\author{
Peter Brosnan*
}

The Republic of Ireland and New Zealand are alike in many respects. They have similarsized populations and similar climates; agriculture has an unusual prominence in their national economies and industrial development is strongly encouraged. In addition, both were once British colonies and have similar legal and political systems with English as their majority language. Despite these, and many other similarities, the two countries have markedly different industrial relations systems. In contrast to New Zealand's state-regulated system, the Irish system is notably voluntaristic, multi-unionism is the norm and Irish unions compete for membership with British-based unions. There are many other differences and this paper highlights the main aspects of the Irish system, covering the collective bargaining system, the union and employer organisations, legislation, Ireland's experience with national pay agreements, participation in management, picketing policy, union restructuring and public sector industrial relations.

\section{The Republic of Ireland}

Ireland's economy and society have been profoundly influenced by its much larger neighbour Britain. The two countries have been linked since the twelfth century and Ireland was incorporated as part of the United Kingdom in 1801. Although Ireland won political independence for 26 of the 32 counties in 1922, the new state's economy remained tied to Britain and most British social institutions were retained.

\section{Economy}

The 1960 s and 1970 s have seen major changes in Ireland's economy. Under British rule, industrial development had been restricted and employment opportunities outside agriculture limited. The situation did not improve much after 1922, and high unemployment rates and emigration, to Britain and other countries, continued to be the norm. However, industrial development began to be promoted vigorously from the late 1950 s and the importance of agriculture has declined - although 17 per cent of the workforce are still employed in that sector. Despite the development of secondary industry, unemployment has continued to be a problem; partly because of the age-structure of the population and partly because the new industries established by foreign firms have been capital- rather than labour-intensive. Nonetheless, Ireland's economy has done much better than Britain's in the last decades and, with the two countries now having similar social security benefits, emigration has reversed and the population ( 3.4 million), which had been declining for over a century, is now increasing.

Despite industrial development, the Irish economy is still very fragile and although Ireland joined the European Community (EC) in 1973, Britain still supplies half of Ireland's imports and takes almost a half of Irish exports. The exceptionally large propor-

* Senior Lecturer, Victoria University of Wellington. This paper was prepared while the author was on leave at Trinity College, Dublin. He wishes to thank Charles McCarthy of that institution and the trade unionists, employers and government officials (too numerous to mention individually) who gave up their time to discuss Irish industrial relations with him. He also wishes to thank Stephen Lalor, David Smith and the Symposium Editor for helpful comments on a draft of the paper. 
tion of national income tied up in exports and imports makes Ireland particularly susceptible to fluctuations in the British and world economies and inflation has been a persistent problem for most of the last decade. Concern about this was one of the factors which led to the negotiation of national pay agreements. Inflation is around 17 percent, while over 10 percent of the workforce is unemployed.

\section{Politics}

The Oireachtas (Irish Parliament) is based on the Westminster model but the two principal political parties, Fine Gael and Fianna Fail, have no modern British counterparts. Both parties are fairly conservative yet do get support from among all sections of the community. The third party, Labour, although founded by the trade unions, is not supported strongly at the ballot box by union members. The working class is more inclined to support Fianna Fail which has formed most governments since 1932 although Fine GaelLabour coalitions have ruled for a total of 10 of those years and regained office as a minority government in June this year.

\section{Industrial Relations System}

While Ireland and New Zealand share many features, the two countries have developed different practices in many areas. But perhaps the greatest difference is in the conduct of collective bargaining. In contrast to New Zealand's state-regulated system, the Irish system is essentially voluntarist. This concept of voluntarism - "the abstention of law and the primacy of voluntary, collective action" (Clegg, 1980, p.290) - has been inherited from Britain and it permeates all aspects of industrial relations to the extent that even arbitration decisions are not binding. In principle, workers are free to join the union of their choice or to withdraw from membership. The parties are not obliged to engage in collective bargaining nor to recognise each other for that purpose. Collective agreements obtained through the bargaining process are not legally binding and the parties to an agreement are responsible for settling disputes over the interpretation of the agreement.

This might appear somewhat anarchic but, in practice, established procedures are followed. The stability of the system relies on union and management organizations jointly regulating industrial relations procedures and we find for example that employers negotiate with unions which are "reasonably representative" of their workforce (or some groups within it) and the Irish Congress of Trade Unions (ICTU) rules stipulate that where a union represents a majority of workers in a negotiation unit, no other union should attempt to organize workers there without permission. Although regulation is by and large left up to unions and employers, the state is more than a disinterested party. It provides certain institutions, such as the Labour Court (described below) to facilitate collective bargaining and the Government has legislated in areas where voluntarism has clearly failed to provide basic rights such as equal pay, redundancy payments or maternity leave. But, while there is a consensus that industrial relations are administered best by the parties themselves, it has always been plain that the state would step in if the parties could not regulate industrial relations in what the Government considered to be a "responsible" manner. For example, government intervention has been a consistent feature of the national pay negotiations. The Government has also legislated to influence trade union structure and has been involved heavily in public sector wage negotiations.

\section{Trade unions}

One consequence of Ireland's British heritage is that British unions still organize workers in Ireland. The majority of workers, however, belong to Irish-based unions and indeed, did so before independence. (McCarthy, 1977B, p.71) The Irish trade union movement had developed a character of its own well before 1922. Dissatisfaction with the British Trade Union Congress led to the formation of an Irish Trade Union Congress (ITUC) in 1894 
mainly comprising British-based craft unions. Exclusively Irish unions continued to form, most noticeably the Irish Transport and General Workers Union (ITGWU), and some branches of British unions broke away to form independent Irish ones. Rivalry between Irish- and British-based unions continued through the years and the Congress of Irish Unions, which affiliated Irish unions only, was set up in 1945 in opposition to the ITUC. The two organisations reunited in 1959 to form the ICTU which affiliates Irish unions and the Irish sections of British unions. Irish unions and the ICTU operate in Northern Ireland as well as in the Republic although the ICTU's Northern Ireland Committee is virtually autonomous.

Ireland has approximately the same degree of union penetration as New Zealand. With 55 percent of all employees belonging to unions, Ireland is one of the most unionised countries in Europe. However, by European standards, it has an unusually large number of unions - at present 85 . Ninety-three percent of unionists belong to ICTU-affiliated unions and just under a half of all union members belong to one of the five general unions. The largest of these, the ITGWU, represents a third of all union members. The British-based unions have 15 percent of the total membership and this proportion may be increasing due to growth in the British-based white-collar unions.

\section{Employers}

The British influence is less strong among management. Multinational companies operating in Ireland have trained local staff for management positions and Irish managers, as well as being relatively young, tend to be outward-looking and identify more readily with Continental or American than with British management. All large organisations maintain industrial relations divisions and it is claimed that most managers have had some training in industrial relations. (cf Blum, 1972, p.76) Industrial relations services are also provided by trade and industry associations. The principal employers' organisation is the Federated Union of Employers (FUE) which was founded in 1911. The FUE has a large membership, maintains regional offices, offers a wide range of services to its members and represents the employer side on national and international bodies.

\section{Legislation}

Rather curiously, various British industrial statutes enacted before 1922 still apply in Ireland with only minor amendments, even though some of them have been repealed in Britain. The most important is the Trades Disputes Act 1906. This Act which is regarded as a "magna carta of industrial relations" is particularly significant because it provides immunity for trade unions and union officials from criminal or civil liability in the event of an industrial dispute, although the Act has been applied more narrowly in Ireland and Irish courts have interpreted the $A c t$ in such a way that it does not apply to public servants nor employees in non-profit making organizations. However, the new coalition Government has stated an intention to widen the Act's coverage.

A fundamental difference between the British and Irish legal systems is Ireland's having a written constitution which, among other things, guarantees freedom of association and the right to strike. However, the courts have interpreted the Constitution very narrowly on these points. (Asmal, 1980 and McCarthy, 1977B, Ch.12) For example, on freedom of association, the Constitution has been interpreted to mean that: (1) persons may join a union; (2) they cannot be forced to join and may withdraw from membership; (3) a union may refuse an application for membership; (4) unions and employers can arrange which union prospective employees will join and (5) members may not transfer between unions without the permission of the ICTU.

Since Ireland joined the European Community in 1973, various new legislation has been passed to fulfill community obligations. The most important has been legislation providing for equal pay; prohibiting discrimination based on sex or marital status; allowing employees with more than one year's service appeal to a tribunal against unjustified dismissal; a requirement for at least 30 days notice of redundancies and a lump sum pay- 
ment in the event of redundancy ( 60 percent of the amount being provided by the state), and granting female employees up to 14 weeks maternity leave with a social welfare payment of 80 percent of their wages and with the right to return to the same or suitable employment.

\section{The Labour Court}

The Irish Labour Court was established in 1946 with the aim of helping the parties to resolve disputes without industrial action. The New Zealand Arbitration Court was used as a model in setting it up but the concept of an industrial court must necessarily be quite different in a voluntarist system. The Labour Court has 12 members: a Chairman, three Deputy Chairmen, four ordinary members nominated by the ICTU and four nominated by the FUE. The Court operates in four divisions of a Chairman and a member from each side. A conciliation service is attached to the Court and the Court proper can only investigate a dispute if the parties have asked it to do so and there has been a failure to settle at conciliation. If the Court hears the case, it will eventually issue a recommendation which, in line with the principle of voluntarism, is not binding. Either party is free to reject it and, in fact, a reasonable number of recommendations are rejected. The point of involving the Court is not to obtain a binding decision but rather to get an independent opinion. The Court will also investigate a dispute where the union side alone requests it; in this case the union must agree to accept the Court's recommendation but even here, the commitment to accept the Court's finding is only a moral one.

Collective agreements can be registered with the Court if both parties agree and the agreement forbids the use of strikes or lockouts before certain procedures are exhausted. The advantage of registration is that the agreement has a similar blanket coverage to New Zealand Awards but, without an adequate enforcement procedure, the advantages of registration are rather ephemeral and it is no surprise to find that very few agreements are registered. The only major one registered is the Building and Construction Industry Agreement.

In addition to its dispute settling functions, the Court also operates two types of regulatory body: Joint Industrial Councils (JIC) and Joint Labour Committees (JLC). JICs, which are established to facilitate collective bargaining in certain industries, have an equal number of employer and union representatives with a chairman either agreed by both sides or nominated by the Court. Agreements achieved by JICs have to be ratified subsequently by the majority of workers and employers affected. In common with other collective agreements, these are not legally binding.

The decisions of JLCs, on the other hand, do have legal backing. JLCs are set up to determine wage rates in industries where the bargaining machinery is very weak. The JLCs are appointed by the Minister for Labour and comprise equal numbers of employer and union nominees plus a number of people from outside the particular industry. JLCs submit proposals for minimum wage rates to the Court which may then issue an order giving effect to the proposals. Once this has been done, firms failing to comply with the order are liable to penalties.

The Court's workload increased greatly during the 1970s. In addition to an increase in the number of disputes coming before it, the Court was being given a new role as a judicial body. This new role came from legislation which designated the Labour Court as a court of appeal against the decisions of certain commissioners. ${ }^{1}$ The National Pay Agreements added further to the workload.

The Labour Court is not legalistic nor bound by precedent, claiming to judge each case on its merits, and seeking an outcome which will produce the best industrial relations.

1 The change in the Court's role from making recommendations solely in disputes of interest to making them also in disputes of right and the inappropriateness of this change, while clearly of importance, will not be developed here. 
(Ireland, 1979B, p.5) In practice, it tends to be conservative and rarely supports new initiatives. The unions have been particularly critical on this score, complaining of government interference, a poor record concerning legal entitlements (especially equal pay), unreasonable delays, secrecy and pro-employer bias. A blatant example of bias occurred in 1975 when the Court overturned the majority decision of a JLC after receiving a private submission from employers. (Role of the Irish Labour Court, 1976) The trend in recent years has been for the Court to regard more and more information as confidential; to the extent that union representatives have been denied the right to inspect assessors' reports in ability-to-pay cases. It is thus no surprise to find unions rejecting the Court's recommendations. The most recent data show that the Court issued 510 recommendations in 1979; of the 117 cases where the Court was notified of rejection or acceptance, one recommendation was rejected by both sides and 48 by the union side. (Ireland, 1979B, p.14)

\section{Trends and Developments}

\section{National Pay Agreements}

The ambiguous role of government in a voluntarist system is highlighted by the Irish Government's involvement in the negotiation of the National Pay Agreements. Since 1970, wage increases have been negotiated centrally by the ICTU and FUE. The ensuing agreements have assigned responsibility for their monitoring and enforcement to the two organizations themselves but it was a government proposal which led to the 1970 Agreement and, on many occasions since, the Government has stepped in to ensure that the system of Pay Agreements continued.

The concept of national agreements is not new to Ireland; central agreements had been negotiated four times between 1946 and 1964. (Browne, 1965) What was new, was the idea that each National Pay Agreement should be succeeded by another. The period prior to 1970 had been dominated by the wage round process. Wage rounds occurred roughly every two years and started by one or other craft union winning a headline settlement provided a norm for the agreements which followed.

Many factors led to the 1970 National Agreement being negotiated but perhaps most important was a lengthy dispute the previous year involving maintenance craft unions. The conduct of this dispute was extremely confused on both sides. It left industrial relations in tatters, the unions deeply divided, and was settled with a 20 percent wage increase which eventually flowed on to other groups. At the same time, inflation was becoming troublesome. The Fianna Fail Government did not see the large settlement to the maintenance craftsmen's dispute as being particularly helpful and expressed the hope that if they controlled prices, the unions would agree to restrict wage demands in the next wage round. A variant of the Government's proposal was discussed by the ICTU 1970 Conference but, finding itself divided, Congress chose to meet with employers in the Employer-Labour Conference. Nothing came of the talks but when the Government seemed about to introduce strict wage controls, the Employer-Labour Conference quickly met again and hammered out a National Pay Agreement. A further National Agreement was negotiated in 1972 and 1974 and, despite reservations on both sides, the system of National Agreements has tottered on with a new Agreement being achieved each year thereafter.

These Agreements are different from previous national agreements in several ways. They are of fixed length, each agreement was followed by another and the Employer-Labour Conference, as well as negotiating the agreement, also supervises its operation and, through its committees, interprets it and conciliates and adjudicates in the case of disputes. The agreements are also different in another but important way in that they have "something of the character of public law" (McCarthy, 1977A, p.121) since they are expected to be observed by employers and unions whether or not they were party to the negotiations. The Government has taken care of the policing when offenders were not affiliated to the ICTU or FUE. This it did in 1973, and again in 1976, when the Irish Bank Officials' 
Association and the banks were set to conclude an agreement outside the terms of the National Pay Agreement; the Fine Gael-Labour Government passed legislation (introduced by the previous Fianna Fail administration) forcing the banks to conform with the National Agreement.

The various National Agreements have differed somewhat in their content. Some have attempted to provide real increases in wages and salaries; most have made some attempt to redistribute income in favour of the more lowly paid. All the Agreements contained an industrial peace clause and as inflation became more serious after 1974, the Agreements provided staged increases linked to changes in the Consumer Price Index.

National Agreements drastically changed the nature of collective bargaining in that wage rates, the central element in company or industry agreements, were decided in advance of negotiations. Some scope still remained for local bargaining over conditions and allowances although this was usually discouraged. Productivity deals provided a loophole for obtaining larger increases since the Agreements permitted larger increases which removed genuine anomalies between different groups and in cases where genuine incentive schemes, or productivity bargains, were negotiated.

The Government welcomed the 1970 Agreement because it saw, in it, the elements of an incomes policy. It also wanted to see a more orderly industrial relations system without the "free-for-all" which characterized the wage round process. It was concerned too by the amount of time lost through stoppages. Inevitably though, the Government became involved for a different reason: its ability to offer subsidies and tax cuts in return for wage restraint. The Government's position on the sideline became more prominent from 1975 when it stepped in and asked that the Agreement under negotiation be amended to a lower rate of wage increase and in return provided various consumer subsidies. Two years later the Government was again negotiating from the wings. It initiated tripartite talks, hoping to trade tax cuts and job creation in return for a wage standstill. This was rejected but the parties eventually agreed to keep wage increases modest in return for a tax-job creation package. The following year,tax cuts were promised if pay increases were limited to 5 percent. Eventually the tax cuts were made when the Agreement set wage increases at 8 percent.

When it was time to negotiate the 1979 Agreement, the Fianna Fail government initiated formal tripartite talks. Following these, a National Understanding for Economic and Social Development was drawn up by the Government, the ICTU and the FUE. The Understanding covered employment, taxation, pay policy, industrial peace, social welfare, participation in management and technical training. The draft document was rejected subsequently by an ICTU special conference on the grounds that it did not do enough for the lower income groups. Fearing a "free-for-all", the Government announced its own guidelines, with a hint that promises made in the National Understanding would be withheld if these were breached. In the light of this threat, agreement was obtained eventually in the Employer-Labour Conference and the first National Understanding was accepted in July 1979. Despite the reservations of many on each side of the bargaining table, another round of on-again off-again negotiations produced a second tripartite National Understanding which was agreed to in December 1980.

\section{Worker Participation}

The range of negotiable issues has expanded in the last decade to include: training, job security, work organisation and the provision of facilities for trade union representatives. National Agreements have not inhibited this trend but, on the contrary, have reinforced it. The Agreements encouraged productivity bargaining which inevitably means a wider range of issues. Furthermore, since local officials were only rubber-stamping the pay elements of the Agreements it was inevitable that, to maintain their legitimacy, they would bargain over other issues. 
Despite the extension of collective bargaining there has been little demand for other forms of participation in company decision making. The small scale of Irish industry is partly responsible for this since job enrichment or work restructuring are hardly relevant in small workplaces. In any case, unions and management have little interest in such schemes. A sub-committee of the Employer-Labour Conference suggested a system of works councils which stressed flexibility and a voluntary approach. The proposed works councils would have been a channel for the disclosure of information to employees - an area where Irish practice lags well behind other EC countries - but while Irish unionists are concerned about disclosure of information,they also have a strong suspicion of institutions which lie outside the normal collective bargaining process. Thus the proposals were never ratified by the Conference.

This suspicion extends to having worker directors sit on company boards. Since 1977, certain state-sponsored bodies can have a third of their directors elected by the workforce from a list of candidates nominated by unions operating in the company. At present, the scheme covers seven organizations and it is planned to extend it to others. Although unions participated in the election of the worker directors, their interest seems to have stopped at that point. They have not used the worker directors for example to promote union interests at the board level and the worker directors' morale is reported to be low.

\section{Stoppages and Picketing}

Ireland has a reputation for being particularly strike-prone. In terms of days lost per worker, there is some justification for this reputation. Ireland has frequently been top or second top of the "international league table". On the other hand, Ireland has fewer stoppages than New Zealand, for example, and also has less workers involved. The Irish statistics tend to be dominated by a small number of lengthy stoppages, sometimes several months long. There are several possible reasons. The more complicated union structure in Ireland is one; employers may find themselves dealing with several unions for each group of workers and agreement has to be reached with them all. Another factor is the dispute settlement procedures which, under a voluntaristic system, are concerned as much with restructuring industrial relations as in merely obtaining a return to work and they appear rather passive in contrast to the panic which characterizes the response to disputes in New Zealand. (See also, Blum, 1972) An interesting feature of Irish stoppages, which is discussed below, is that the major stoppages often occur in the public sector. The longest of recent years occurred in the Post Office in 1979, lasting for 18 weeks and being responsible for about one million man-days lost. ${ }^{2}$

The maintenance craftsmen's dispute of 1969 , as well as being a factor in the decision to negotiate National Agreements, also affected the nature of picketing. Picketing is very common in Irish disputes and is frequently commented on by foreign observers. It is perceived as a source of great annoyance by management, especially in conjunction with unofficial strikes since Irish blue-collar workers have great solidarity - at least on this issue - and do not cross pickets even if their union instructs them to. ${ }^{3}$ So much so, that it has been suggested by some employers that unofficial pickets should not bè protected by the Trade Disputes Act. But uncontrolled picketing can also be annoying to workers who may find a picket line at their workplace in conjunction with a dispute which does not affect them and about which they have not been consulted. This problem became particularly serious during the maintenance dispute since the craftsmen applied pickets at places where only a few of their own members worked. The craftsmen's action was entirely successful in

One of the longest disputes involved electricians in CIE (the national transport corporation) and lasted for over a year. This is not to say that long stoppages do not occur in private industry; the banks were closed for six months during 1970.

See I.L.O., 1975, p.10; Ireland, 1968, p.35; McCarthy, 1973, pp.18, 102, 105, 107. 
stopping work at the picketed plants. The greatest costs, however, were borne by the members of other unions in those plants. Some of these suffered very seriously as a result of the picketing and it was even suggested that the picketed plants had been chosen so as to maximize the effect of the action on employers while minimizing the cost to the craft unions themselves. (McCarthy, 1973, p.159-160) Eventually some of the other unions mounted retaliatory pickets. As McCarthy put it:

Rarely was there such evidence of division: executive committee against strike committee, amalgamated against national, building against engineering and, within the same union, representative against representative. . . The trade union side had fallen into a squalid domestic wrangle which was resolved ultimately only by the complete capitulation of the employers.

In this situation it was clear that something would have to be done.

$(1973, p .165-6)$

Accordingly, the 1970 ICTU conference endorsed a proposal whereby Congress would be the only body which could authorize a general stoppage in a firm or industry. Thus there are now two types of official strike: the individual union strike with a union picket which may be crossed by members of other unions and the all-out strike with an ICTU picket. In terms of conserving the union movement's strike power, the policy has had only limited success; blue-collar workers are still reluctant to cross the picket of another union. On the other hand, the threat of an all-out strike is a very powerful weapon. A request for an all-out picket is referred by the ICTU to the other unions affected. Although requests for all-out pickets are granted in almost every case, in practice the threat of an all-out strike is usually sufficient to make the employer side resume negotiations.

\section{Trade Union Restructuring}

The structural diversity of the Irish trade union movement with its division into craft/ general, white-collar/blue-collar and Irish/British-based unions is seen by many inside and outside the movement to be a serious weakness. The overlapping jurisdictions of the various unions in a workplace leads to direct competition between unions, and a certain amount of inter-union hostility, which further complicates the already difficult task of coordinating their activities. ${ }^{4}$ Other concerns are the prevalence of small unions - most have less than 1500 members - and the low level of fees (although they are higher than in New Zealand) with consequent poorer service for members. Structural problems were of concern to the union movement even before the creation of the Irish Free State (McCarthy, 1977B, passim) These problems were highlighted during the maintenance dispute and the divisions caused by that dispute were so deep that, as part of the subsequent patching up, it was decided to invite the ILO to present a report on restructuring the union movement. The ILO report (1975) made some very modest suggestions but there is no sign that these will be implemented in the near future.

Governments have also endeavoured to encourage union restructuring. One attempt was made by a Fianna Fail administration which introduced trade union licensing in 1941. The legislation restricted the protection provided by the Trade Disputes Act 1906 to unions which hold negotiation licences but constitutional problems reduced the Act's effectiveness. The process of forming a new union has become more difficult since 1971. A negotiating licence will be granted now only to a union which has had at least 500 members for a minimum of 18 months. On top of this, 18 months notice must be given and $£ 5000$ deposited with the High Court. A carrot for unions to amalgamate is dangled by the Trade Union Act 1975 which has simplified the process of amalgamation and provides financial assistance to defray the costs of the amalgamation.

Despite this, only a few unions have amalgamated and wholesale amalgamations are

4

These problems are highlighted by the case studies in McCarthy (1973). Similar comments are made by Fogarty (1980) and in ILO (1975). 
unlikely in the near future. Small unions do not want to be swallowed up by large ones. There is a certain sentimentality about the existing unions and the white-collar and craft unions do not want to lose their exclusivity. Needless to say, it is not practical for Irishand British-based unions to merge. McCarthy has pointed out that nationalism has been a prime motivating force for restructuring in the past; with Irish nationalist feelings now at a lower ebb, the dynamic for change is much less. (C. McCarthy, 1979, p.305; also McCarthy, 1977B, especially Ch.3).

\section{The Public Sector}

Close on one out of every three Irish workers is employed in the public sector. The sector is conventionally divided into two sub-sectors: the state sector and the semi-state sector. The former includes the Civil Service, Teaching Service, Defence, Police and Local Authorities. The semi-state sector includes nationalized industries and state-sponsored bodies such as Aer Lingus, the Pigs and Bacon Commission or the Irish Development Authority. The semi-state sector uses similar negotiating procedures to the private sector although some organisations use special councils or tribunals of their own as a first stage, with reference to the Labour Court where agreement cannot be reached.

The state sector on the other hand uses a conciliation and arbitration system. The system varies somewhat within the state sector but most schemes have one conciliation council where the Official Side (management) and Staff Side (unions) negotiate under the direction of an Official Side chairperson. The Civil Service scheme has a General Council to deal with service-wide matters and Department Councils for matters affecting single departments. The Councils discuss a wide range of issues and prepare reports recording points of agreement and disagreement which are sent to the appropriate Minister who nearly always accepts their recommendations.

Arbitration is available where agreement cannot be reached in conciliation but the range of arbitrable issues is restricted essentially to wages and hours. Arbitration Boards have an independent chairperson appointed by the Government in agreement with the Staff Side. The remainder of the Board comprises Official and Staff Side representatives and, in some cases, two Labour Court members. Arbitration is not binding on either side; the Boards' report may be rejected by the Staff Side, in the same way that Labour Court decisions may be rejected in the private sector. If the Official Side accepts the Board's report, it is presented to the Dail (the lower house) which may accept, reject or modify it.

A substantial proportion of working days lost through industrial disputes are lost in the public sector. This is inevitable, given the numbers working in the sector and the size of the employing units, but disputes in the public sector do tend to be lengthy. When it comes to facing a stoppage, public sector managers are more hard-nosed than their private sector colleagues. Private sector employers losing profits from a strike are more inclined to settleup. in the public sector, management is more likely to sit-it-out. There are two interrelated reasons for this: government attitude towards public sector pay and the tight relativities which apply within the sector.

Irish governments have not reconciled properly their conflicting roles as employer and government. Rather than seeing public sector wages as the price of labour in that sector, they view them as a drain on the exchequer. The consequence is a feudal attitude towards public sector pay and employment and government has tried to use public sector pay as an instrument in its strategy for economic management: It was this sort of thinking which caused the Government to embargo in 1975 all special increases for the sector, despite this being held by the Employer-Labour Conference to be a breach of the National Agreement. This decision caused much tension within the public sector, especially at a time when some private sector groups were gaining large increases through dubious productivity claims, and was one of the factors eventually responsible for the lengthy Post Office stoppage in 1979. This attitude towards public sector pay is compounded by the strict relativities which apply within the sector. 
Each pay rate within the public sector is perceived as being related to another. Given the smallness of the country and the ease with which information about relative pay rates can be obtained, a movement in pay by one group means relativity claims by related groups. To complicate matters further, some groups, especially in the semi-state bodies, have clear comparability with groups in the private sector and the different groups within the public sector have different wage setting mechanisms from each other. The stage is thus set for movements in the private sector to be transmitted to the public sector and then to raise eventually wages in the whole sector. A dispute in any part of the public sector therefore has implications far beyond the confines of the particular dispute. Coupled with this, there is the problem that public sector managers, even in the semi-state sector, do not have the money to pay increases without going to the exchequer. Consequently, the Staff Side in any dispute finds that it is really negotiating with the Public Service Department, and ultimately the Government, who are reluctant to allow increases because of their implications for government expenditure.

Public sector pay slipped well behind the private sector during the first six years of the National Agreements but has tended to hold its own since 1977 and a number of very large catch-up increases have been awarded recently. As well, Civil Service unions have become more militant. Civil Service clerical workers engaged recently in limited industrial action the only case of action by the Civil Service unions apart from the Post Office dispute. The newly-elected Fine Gael-Labour Government's first budget directed public sector employers to invoke the inability-to-pay clause of the National Understanding. Given the increased militancy in the Civil Service, it will be interesting to see how this U-turn in public sector pay movements is accepted.

\section{The Future?}

Predicting the immediate future is relatively easy since the new Fine Gael-Labour Government has outlined its intentions. It has stated it will implement the EC directive on disclosure of information, encourage the election of worker directors to the boards of large companies, extend the Trades Disputes Act to the public sector and, in the light of a recent court decision which raised doubts about the legality of the ICTU all-out picket, legislate, if necessary, to protect the picketing policy.

Will National Pay Agreements continue? Support from individual employers and unions is less than unanimous but the system of National Agreements is a very difficult treadmill to get off. All can see the pressures which build up at local level as a result of the agreements but most fear the consequences of reverting to unfettered local bargaining. The new Government has indicated clearly its support for a National Understanding. The unions, in principle, support the concept of a further agreement but are disappointed at the government side's performance in honouring commitments in the previous Understanding. The employers also support the principle but are playing hard to get; a recently released FUE document calls for a statutory pay pause, followed by a new Understanding incorporating maximum increases in total pay for each firm with local bargaining over the allocation of the increases. (Fogarty, et al., 1981) The employer proposals will not be accepted by the union side and the outcome will most likely be another National Understanding with possibly a little more freedom for local-level bargaining.

On a longer term basis the essential question is: Will the principle of voluntarism survive? The 1970s have certainly seen an increase in government involvement; in the National Pay Agreements and in the provision of positive legislation in certain areas and ironically the Irish system has retreated somewhat from unfettered voluntarism as the New Zealand system has experienced some liberalization of collective bargaining. A Commission of Inquiry into Industrial Relations was set up in 1978 and although the Commission's report had not been released yet, it was rumoured to recommend a greater use of the law in industrial disputes. However, the Commission's report cannot be taken seriously since the trade union members withdrew shortly after the Commission was formed. While some 
individual employers would favour more compulsion, the FUE generally does not. Nonetheless, they would go so far as to argue that the Trades Disputes Act should apply only in "constitutional" strikes where certain procedures have been followed. However, the unions, for their part, favour the continuation of voluntarism while welcoming the provision of positive legislation in the areas where it has failed. This would also be the position of the new Government for the Minister of Labour has stated his policy is that disputes should be settled by the parties themselves and that the Minister should not intervene. The few occasions when Ireland applied legal coercion in industrial relations turned out to be unhappy experiences; possibly the only exception were the Acts regulating salaries in the banks and that was acceptable only because the banks and their employees were forced to do what other unions and employers had chosen to do voluntarily. Given that employers' support for greater compulsion is only lukewarm and that the unions and government are strongly opposed to the extension of legal coercion, voluntarism should remain the basic philosophy of the Irish industrial relations system.

\section{References}

Asmal, K. (1980) The Constitution, the law and industrial relations. In Nevin (Ed).

Blum, A. (1972) Strikes salaries and the search for solutions: an interpretive analysis of the Irish industrial relations system British journal of industrial relations 10:62-83.

Boyd, A. (1972) The rise of the Irish trade unions Tralee, Anvil.

Brown, M.H. (1965) Industrial labour and incomes policy in the Republic of Ireland British journal of industrial relations 3: 46-66.

Central Bank of Ireland (1981) Annual report Dublin.

Chubb, B. (1974) The govermment and politics of Ireland London, Oxford.

Clegg, H.A. (1980) The changing system of industrial relations in Great Britain Oxford, Blackwell.

Daly, M.E. (1979) Women work and trade unionism. In M. MacCurtain and D. O'Corrain (Eds) Women in Irish society: the historical dimension Dublin, Arlen House.

European Foundation for the Improvement of Living and Working Conditions (1981) The Worker Director and his impact on the enterprise Dublin.

Fogarty, M.P. (1980) Trade unions and the future. In Nevin (Ed).

Fogarty, M.P., D. Egan and W.J.L. Ryan (1981) Pay policy for the 1980s Dublin, Federated Union of Employers.

Hillery, B., A. Kelly and A. Marsh (1975) Trade union organisation in Ireland Dublin, Irish Productivity Centre.

Hillery, B. (1980) Industrial relations: compromise and conflict. In Nevin (Ed).

I.L.O. (1975) Restructuring of the Irish trade union movement (Memorandum submitted to the Irish Congress of Trade Unions) Geneva.

Ireland (1968) Final report of the Committee on Industrial Relations in the Electricity Supply Board Dublin.

Ireland (1979A) Employment Equality Agency Annual report Dublin.

Ireland (1979B) Labour Court Thirty-third annual report Dublin.

Ireland (1979C) Review Body on Higher Remuneration in the Public Sector Report No. 20 Dublin.

Irish Congress of Trade Unions (various dates) Trade union information Dublin.

Kavanagh, L.P. (1981) A comparative analysis of some industrial relations processes in the state and semi-state sectors Thesis (M.Sc. [Mgmt]). Trinity College, Dublin.

Krislov, J. (1972A) Irish attitudes regarding conciliation: a survey of management, labour and conciliation officers Industrial relations 3: 43-48. 
Krislov, J. (1972B) The participants' view of the Appeals Board of the Irish Congress of Trade Unions Northern Ireland legal quarterly 23: 190-203.

Lee, J.J. (1980) Worker and society since 1945. In Nevin (Ed).

McCarthy, C. (1973) The decade of upheaval: Irish trade unions in the nineteen sixties Dublin, Institute of Public Administration.

McCarthy, C. (1977A) A review of the objectives of the National Pay Agreements 19701977 Administration 25: 120-136.

McCarthy, C. (1977B) Trade unions in Ireland 1894-1960 Dublin, Institute of Public Administration.

McCarthy, C. (1979) Industrial relations: some strategies for change Administration 27: 294-321.

McCarthy, E. (1979) Women and work in Ireland: the present and preparing for the future. In M. MacCurtain and D. O'Corrain (Eds) Women in Irish society: the historical dimension Dublin, Arlen House.

McCarthy, W.E.J., J.F. O'Brien and V.G. Dowd (1975) Wage inflation and wage leadership: a study of the role of key bargaining in the Irish system of collective bargaining Dublin, Economic and Social Research Institute (Paper No. 79).

McGinley, M. (1976) Pay negotiations in the public service Administration 24: 76-95.

Nevin, D. (ed) (1980) Trade unions and change in Irish society Dublin, Mercier.

O.E.C.D. (1979) Wages policy and collective bargaining developments in Finland, Ireland and Norway Paris.

O'Hagan, J.W. (Ed) (1978) The economy of Ireland Dublin, Irish Management Institute. Productivity bargaining trends (1979) European industrial relations review · 64: 19-20.

Role of the Irish Labour Court (1976) European industrial relations review 28: 12-14.

Sams, K.I. (1968) The Appeals Board of the Irish Congress of Trade Unions British journal of industrial relations 6: 204-209.

Sweeney, P. (1980) Industrial relations: realities. In Nevin (Ed)

Wayne, N. (1980) Labour law in Ireland Dublin, Kincora. 